\title{
Penerapan Model Inkuiri Terbimbing Untuk Meningkat Sikap Ilmiah Dan Hasil Belajar Siswa Pada Konsep Alat-Alat Optik Kelas XI SMAN 1 Mukomuko
}

\author{
Siti Fadilah, Andik Purwanto, Eko Risdianto \\ Prodi Pendidikan Fisika FKIP-UNIB \\ Email: Sitifadilah165@gmail.com
}

\begin{abstract}
Penelitian ini merupakan penelitian tindakan kelas (PTK) yang bertujuan untuk mengukur peningkatan sikap ilmiah, hasil belajar dan aktivitas belajar siswa pada konsep Alat-Alat Optik yang dilakukan dalam tiga siklus. Subjek dalam penelitian ini adalah seluruh siswa kelas XI IPA 4 yang berjumlah 35 orang. Hasil penelitian ini menunjukkan bahwa sikap ilmiah pada siklus I sebanyak 8 siswa pada kategori baik, pada siklus II 23 siswa, dan meningkat pada siklus III 28 siswa. Hasil belajar siswa aspek pengetahuan pada siklus I diperoleh ketuntasan belajar sebesar 60\% (belum tuntas), meningkat pada siklus II diperoleh ketuntasan belajar sebesar $80 \%$ (belum tuntas), dan meningkat pada siklus III diperoleh ketuntasan belajar sebesar 88,6\% (tuntas). Hasil belajar aspek keterampilan pada siklus I diperoleh sebesar 72,26, pada siklus II sebesar 77,8, siklus III sebesar 84, pada predikat terampil. Aktivitas belajar siswa pada siklus I dengan rata-rata skor sebesar 38 pada kategori aktif, siklus II sebesar 42 pada kategori aktif dan siklus III sebesar 46,5 pada kategori aktif. Berdasarkan hasil penelitian dapat disimpulkan bahwa penerapan model pembelajaran inkuiri terbimbing dapat meningkatkan sikap ilmiah, hasil belajar dan aktivitas belajar siswa kelas XI IPA 4 SMAN 1 Mukomuko pada konsep Alat-Alat Optik.
\end{abstract}

Kata Kunci: Model Inkuiri Terbimbing, Sikap ilmiah siswa, Hasil belajar, Aktivitas belajar siswa.

\begin{abstract}
Research is classroom action research that aims to measure the improvement of scientific study, learning outcomes, dan study activity on the concept of optical devices performed in three cycles. The subject of this research is all students of XI IPA 4 which the total is 35 people. The result shows that, in scientific study, first cycle is good for 8 students, then in the second cycle is got 23 students and the third cycle is got 28 students. The report in knowledge aspect is got $60 \%$ of study completeness (not completed), then increased to be $80 \%$ in the second cycle (not completed) and then increased to be 88 , $6 \%$ (completed) in the third cycle. In skill, the report for the first cycle is 72,3 , then in the second cycle, it is got 77, 8 and then in the third cycle, it is got 81 , which means skill in study activity, first cycle, students got 38 in active category. In the second cycle, they got 42 in active category and third cycle, thay got 46,5 in activecategory. Based on the results, it is concluded that implementation of inquiry model guideline can improve scientific study, final report and study activity of XI IPA 4 SMAN 1 Mukomuko by using optical instrument concept.
\end{abstract}

Keywords : Inquiry Model Guideline, Scientific Study, Learning Outcomes, Study Activity.

\section{PENDAHULUAN}

Pembelajaran fisika saat ini sangat menekankan pada orientasi siswa sebagai subjek dalam proses pembelajaran. Hal ini sejalan dengan diterapkannya kurikulum 2013. Kurikulum 2013 menekankan adanya proses saintifik di dalamnya sehingga perlunya model pembelajaran yang sesuai dengan pendekatan saintifik tersebut. Model pembelajaran yang digunakan dalam kurikulum 2013 ditekankan untuk menggunakan proses saintifik.

Pendekatan saintifik merujuk pada kriteria sebagai berikut; 1) Materi pembelajaran berbasis pada fakta atau fenomena yang dapat dijelaskan dengan logika atau penalaran tertentu bukan sebatas kira-kira, khayalan, legenda, atau dongeng semata, 2) Penjelasan guru, respon siswa, dan interaksi edukatif guru-siswa terbebas dari prasangka yang serta-merta, pemikiran subjektif, atau penalaran yang menyimpang dari alur berpikir logis, 3) Mendorong dan menginspirasi siswa berpikir secara kritis, analisis, dan tepat dalam mengindetifikasi, memahami, memecahkan masalah, dan mengaplikasikan materi pembelajaran, 4) Mendorong dan menginspirasi siswa mampu berpikir hipotetik dalam melihat perbedaan, kesamaan, dan tautan satu sama lain dari materi pembelajaran, 5) Mendorong dan menginspirasi siswa 
mampu memahami, menerapkan, dan mengembangkan pola berpikir yang rasional dan objektif dalam merespon materi pembelajaran, 6) Berbasis pada konsep, teori, dan fakta empiris yang dapat dipertanggungjawabkan, 7) Tujuan pembelajaran dirumuskan secara sederhana dan jelas, namun menarik sistem penyajiannya ${ }^{[4]}$

Berdasarkan hasil observasi dan wawancara yang telah dilakukan dengan guru fisika di SMAN 1 Mukomuko, didapatkan bahwa proses pembelajaran fisika yang dilakukan di dalam kelas masih menggunakan pembelajaran konvensional, di mana metode pembelajaran yang digunakan metode ceramah, tanya jawab, dan masih sering pemberian tugas bersifat individual. Sehingga siswa kurang aktif dan kurang semangat dalam menemukan, mencari serta membangun pengetahuannya sendiri.

Pembelajaran fisika yang masih dilakukan dengan cara-cara konvensional, menyebabkan pembelajaran fisika hanya berlangsung di dalam kelas saja sehingga sangat jarang menggunakan alat peraga ataupun melakukan eksperimen/percobaan. Padahal laboratorium di SMAN 1 Mukomuko masih bagus dan alat-alat laboratorium masih lengkap dan layak untuk digunakan. Pembelajaran yang lebih sering dilakukan di kelas menyebabkan sikap ilmiah siswa masih rendah adalah kurang dibiasakannya siswa dihadapkan pada masalah nyata yang ada di kehidupan sehari-hari.

Faktanya di SMAN 1 Mukomuko sudah menerapkan kurikulum 2013 namun belum maksimal , terlihat dari model pembelajaran yang digunakan. Maka untuk mewujudkan siswa yang memiliki sikap ilmiah dan hasil belajar yang diharapkan maka diperlukan inovasi dalam pembelajaran yaitu dengan menggunakan model pembelajaran yang dapat mengajak siswa untuk mencari, menemukan dan membangun pengetahuannya sendiri, model pembelajaran yang dapat menunjang sikap ilmiah siswa, sehingga dapat meningkatkan hasil belajar siswa yaitu dengan menerapkan pembelajaran menggunakan inkuiri terbimbing. Dalam penelitian ini diharapkan dengan menerapkan model pembelajaran inkuiri terbimbing dapat meningkatkan hasil belajar, selain itu diharapkan juga dalam proses pembelajaran inkuiri ini dapat memunculkan sikap ilmiah siswa, hal ini sesuai dengan pernyataan Abdurrahman mengenai hasil belajar yang menyatakan bahwa "Hasil belajar adalah kemampuan yang diperoleh anak setelah melalui kegiatan belajar" "3]. Permasalahan ini juga terjadi dalam proses pembelajaran. Kebanyakan siswa kurang antusias dalam membaca dan mempelajari materi yang diajarkan, malu bertanya tentang materi yang kurang mereka pahami serta tidak berani mengemukakan pendapat. Selain itu rasa tanggung jawab dan kerjasama dalam diri siswa juga masih kurang. Rendahnya sikap ilmiah ini dikarenakan proses pembelajaran hanya mengutamakan hasil belajar saja tanpa melihat sikap ilmiah siswa.

Untuk dapat mengembangkan kemampuan siswa secara maksimal, mulai dari kemampuan intelektual hingga kemampuan keterampilan siswa kita dapat menggunakan model inkuiri, sesuai dengan pendapat Purwanto \& Lubis yang menyatakan bahwa model pembelajaran inkuiri merupakan suatu proses untuk mengembangkan kemampuan intelektual siswa mulai dari kemampuan emosional maupun kemampuan keterampilan. Kemampuan intelektual siswa akan terlihat dari cara siswa merumuskan masalah dan membuat suatu hipotesis terhadap suatu permasalahan, kemampuan emosional terlihat dari cara siswa bekerja dalam kelompoknya saling membagi tugas maupun pengetahuan, sedangkan kemampuan keterampilan terlihat dari cara siswa menggunakan alat-alat laboratorium dalam pelaksanaan eksperimen $^{[6]}$.

\section{METODE PENELITIAN}

Penelitian ini merupakan penelitian tindakan kelas (PTK) atau Classroom Action Research. Prosedur penelitian tindakan kelas yang dilaksanakan berupa proses pengkajian bertahap yang terdiri dari 4 tahap yaitu: 1) perencanaan tindakan, 2) pelaksanaan tindakan, 3) observasi dan 4) analisa dan refleksi. Pelaksanaan pembelajaran terdiri atas 3 siklus. Teknik pengumpulan data yang digunakan adalah test siklus, observasi, dan angket. Data yang 
diperoleh adalah aktivitas belajar siswa dan aktivitas guru, hasil belajar fisika aspek pengetahuan dan aspek keterampilan dan sikap ilmiah siswa.

Teknik analisis data hasil belajar fisika aspek pengetahuan dalam penelitian ini dengan mencari nilai rata-rata , Standar Deviasi (SD), Daya Serap (DS), Ketuntasan Belajar Secara Klasikal (KB). Aspek keterampilan menggunakan skala 0-100 merupakan gabungan dari dari penilaian observasi keterampilan dan laporan siswa (LKPD). Dengan nilai keterampilan tuntas apabila $\geq 75$ sesuai dengan KKM yang telah ditetapkan sebelumnya.

Penilaian sikap ilmiah siswa merupakan penilaian angket yang di isi oleh siswa di akhir pembelajaran. Dengan kisaran nilai dalam kategori seperti pada tabel 1 berikut ini.

Tabel 1. Penilaian Interval Kategori sikap ilmiah siswa

\begin{tabular}{ccc}
\hline No & Kategori skor angket sikap ilmiah & Interval \\
\hline 1. & Kurang & $17-29$ \\
\hline 2. & Cukup & $30-42$ \\
\hline 3. & Baik & $43-55$ \\
\hline 4. & Sangat Baik & $56-68$
\end{tabular}

Aktivitas belajar siswa dan aktivitas guru merupakan penilaian observasi dari dua orang pengamat. Dengan kisaran nilai dalam kategori seperti pada tabel 2 berikut ini.

Tabel 2. Interval Kategori penilaian observasi aktivitas belajar siswa dan guru

\begin{tabular}{ccc} 
No & Kategori & Interval \\
$\mathbf{1}$ & Kurang Baik & $16-26$ \\
$\mathbf{2}$ & Cukup Baik & $27-37$ \\
\hline $\mathbf{3}$ & Baik & $38-48$ \\
\hline
\end{tabular}

\section{HASIL DAN PEMBAHASAN}

\subsection{Hasil}

\subsubsection{Hasil Sikap Ilmiah Siswa} ini.

Untuk jumlah nilai sikap ilmiah siswa tiap siklusnya dapat dilihat pada gambar 1 berikut

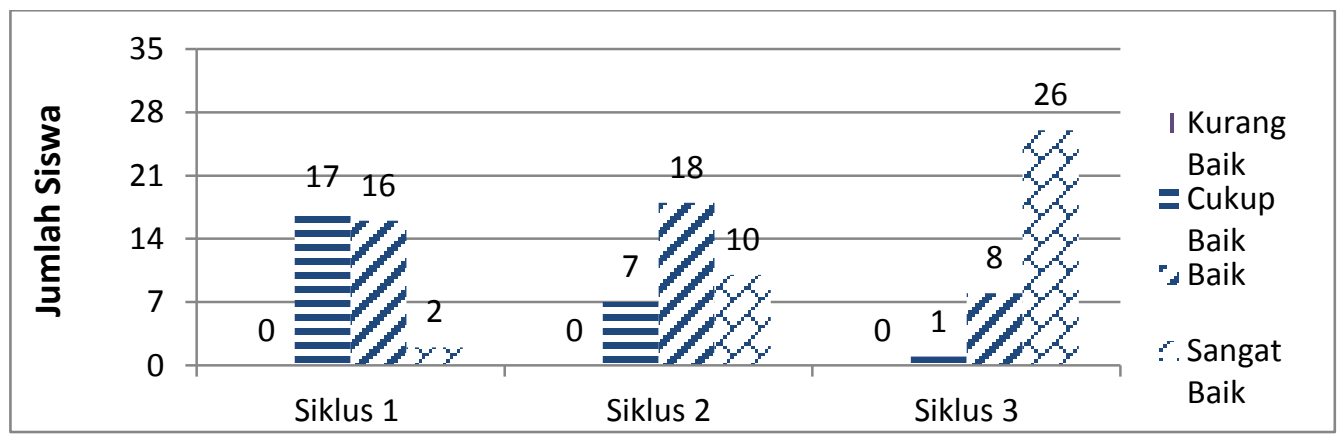

Gambar 1. Grafik Peningkatan Sikap Ilmiah Siswa

\subsubsection{Hasil Belajar Fisika Siswa}

\section{Hasil Belajar Aspek Pengetahuan}

Data hasil belajar fisika siswa aspek pengetahuan dari siklus ke siklus dapat dilihat pada gambar 2 sebagai berikut: 


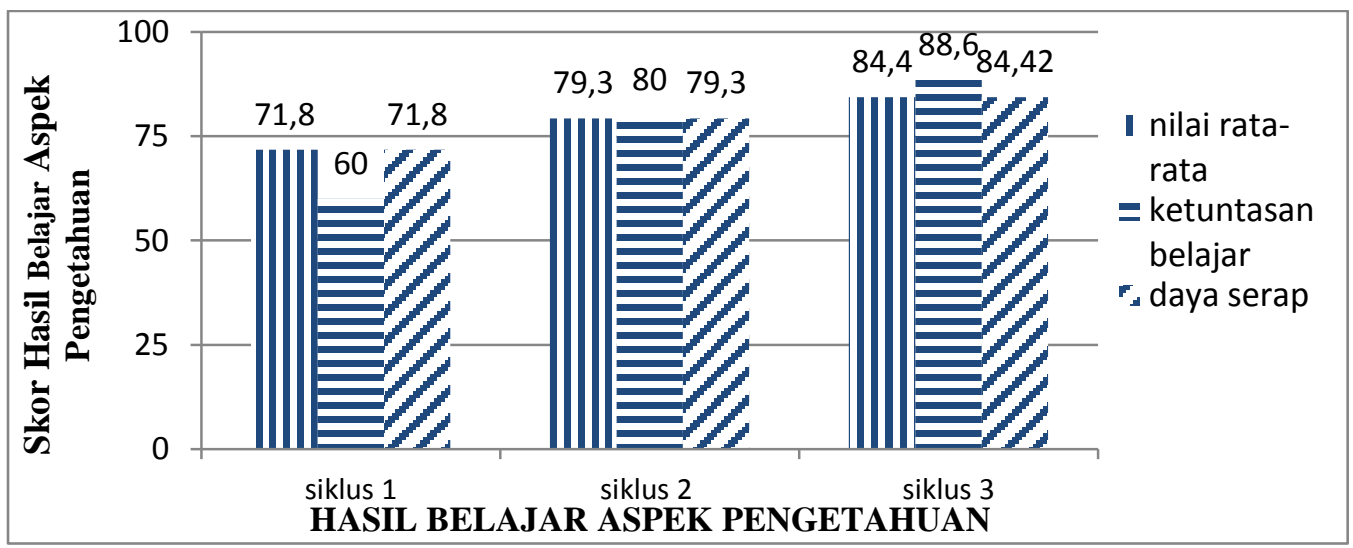

Gambar 2. Grafik Nilai Pengetahuan Setiap Siklus

\section{Hasil Belajar Aspek Keterampilan}

Data hasil belajar fisika siswa aspek keterampilan dari siklus ke siklus dapat dilihat pada gambar 3 sebagai berikut :

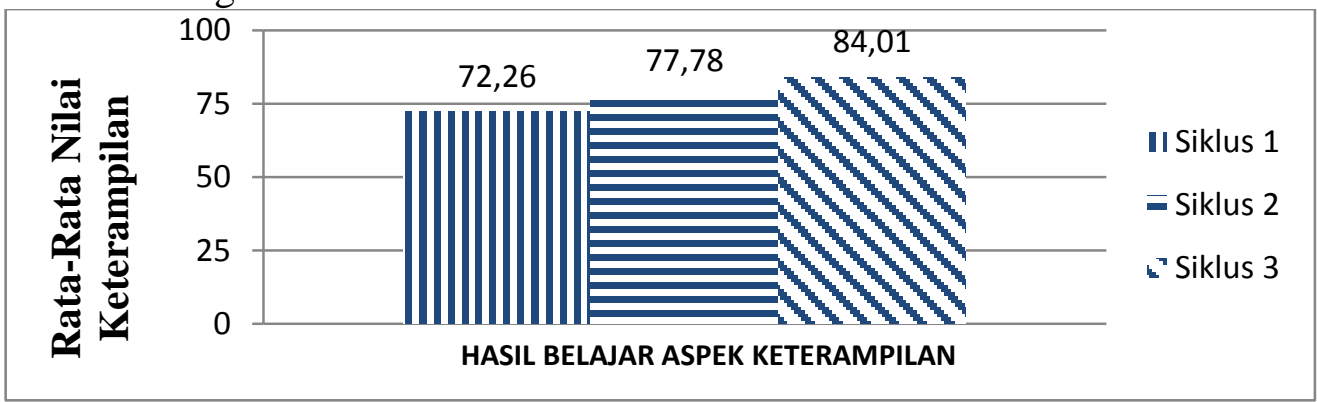

Gambar 3. Grafik Hasil Belajar Aspek Keterampilan Siswa

\subsubsection{Hasil Observasi Aktivitas Belajar Siswa}

Hasil observasi aktivitas belajar siswa dari siklus ke siklus dapat dilihat pada gambar 4 sebagai berikut :

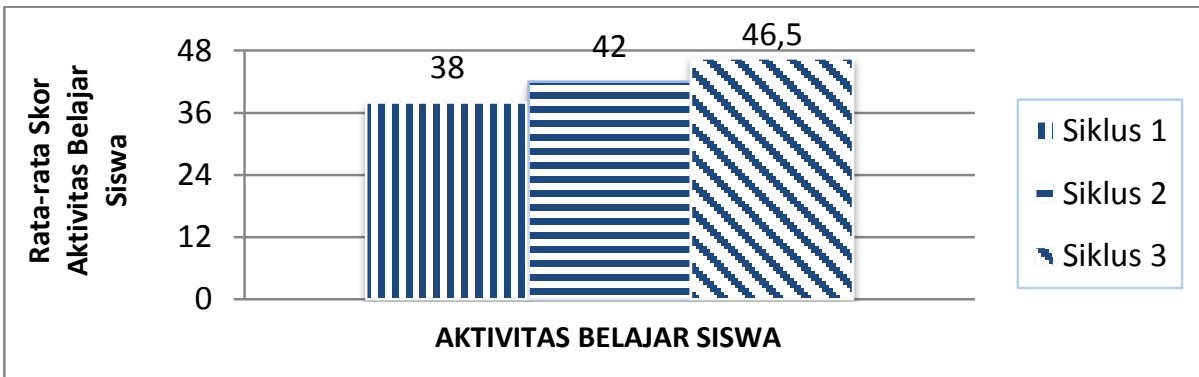

Gambar 4. Skor Rata-rata Aktivitas Belajar Siswa

\subsection{Pembahasan}

\subsubsection{Deskripsi Sikap Ilmiah Siswa}

Berdasarkan hasil penelitian dapat dilihat bahwa jumlah siswa dalam tiap kategori selalu mengalami peningkatan. Secara keseluruhan sikap ilmiah siswa mengalami peningkatan dari siklus I sampai siklus III. Dimana pada siklus I hanya 2 siswa dikategorikan sangat baik,16 siswa dikategorikan baik dan 17 siswa dikategorikan cukup baik, pada siklus II sebanyak 10 siswa dikategorikan sangat baik, 18 siswa dikategorikan baik dan 7 siswa dikategorikan cukup baik, pada siklus III meningkat menjadi 26 siswa dikategorikan sangat baik, 8 siswa dikategorikan baik dan hanya 1 siswa yang dikategorikan cukup baik.

Sikap ilmiah secara keseluruhan sudah pada kategori sangat baik, artinya sikap ilmiah siswa ketika melakukan proses ilmiah berupa percobaan dalam pembelajaran sudah terlihat atau sudah baik dengan menerapkan model pembelajaran inkuiri terbimbing walaupun peningkatannya tidak terlalu tinggi. Hal ini dikarenakan untuk meningkatkan sikap ilmiah 
siswa perlu proses pembelajaran berkesinambungan, secara terus menerus, intensif dan memerlukan waktu yang lama untuk melihat perubahan yang tinggi dari sikap ilmiah seorang siswa tersebut. Sikap ilmiah pada penelitian ini ditumbuhkan dan dikembangkan lewat percobaan yang dilakukan siswa setiap siklusnya. Siswa dibimbing dalam melakukan penyelidikan sesuai dengan langkah-langkah setiap siklusnya.

Berdasarkan uraian sebelumnya, maka siswa mengalami peningkatan pada sikap ilmiah dengan mengikuti proses pembelajaran melalui penerapan model pembelajaran inkuiri terbimbing. Peningkatan sikap ilmiah juga dipengaruhi oleh peningkatan aktivitas belajar siswa, sehingga dapat disimpulkan bahwa peningkatan sikap ilmiah siswa merupakan dampak yang ditimbulkan dari meningkatnya aktivitas belajar siswa, hal ini sejalan dengan hasil penelitian Maizora yang menyatakan bahwa "meningkatnya sikap ilmiah siswa juga diiringi oleh peningkatan aktivitas belajar siswa"'[5].

\subsubsection{Deskripsi Hasil Belajar Siswa \\ Hasil Belajar Aspek Pengetahuan}

Dapat dilihat siklus I dengan nilai 71.8 kemudian meningkat ke siklus II dengan skor 79.3, kemudian meningkat lagi ke siklus III dengan nilai 84. Pada siklus I dengan skor 71.8 dengan kategori tidak tuntas artinya secara rata-rata klasikal siswa belum menguasi materi yang telah diajarkan guru . Dimana jumlah siswa yang tuntas pada siklus I adalah 21 orang dan 28 orang lainnya tidak tuntas. Siklus I pun secara klasikal hasil belajar siswa aspek pengetahuan belum dapat dikatakan tuntas karena hanya 60\%. Hal ini terjadi karena ada beberapa siswa yang belum memperhatikan betul pada saat guru menerangkan materi. Pada siklus II terjadi peningkatan skor rata-rata yaitu 79.3 dikatagorikan belum tuntas. Hasil belajar siklus II ini juga dikatakan belum tuntas secara klasikal karena hanya $80 \%$. Dimana jumlah siswa yang tuntas hanya 21 Orang dan tidak tuntas sebanyak 28 orang siswa. Hal ini dikarenakan pada siklus II siswa masih kurang dalam memperhatikan guru. Sedangkan pada siklus III skor rata-rata hasil belajar pengetahuan adalah 84.4 dapat dikatakan siswa secara rata-rata sudah menguasai materi yang telah diajarkan dengan menerapkan pendekatan saintifik dengan menggunakan model pembelajaran inkuiri terbimbing. Ketuntasan klasikal sudah mencapai $88.6 \%$ hanya terdapat 4 orang siswa yang belum tuntas.

Daya serap siswa dari siklus I hingga siklus III mengalami peningkatan. Begitu juga ketuntasan belajar secara klasikal, untuk siklus I ketuntasan secara klasikal siswa belum dikatakan belum tuntas karena siswa yang tuntas tidak mencapai $\geq 85 \%$ tetapi hanya $60 \%$. Hal ini disebabkan karena siswa kurang serius dalam mengikuti pembelajaran pada siklus I. Namun, kekurangan-kekurangan ini diperbaiki untuk siklus selanjutnya sehingga untuk siklus selanjutnya mengalami peningkatan yang. Pada siklus III ketuntasan belajar siswa telah mencapai $88.6 \%$ artinya sudah tuntas secara klasikal. Peningkatan daya serap juga ditunjukan pada setiap siklusnya dimana pada siklus I daya serap siswa sebesar $71.8 \%$, siklus II sebesar $79.3 \%$, siklus III sebesar $84.4 \%$. tes siklus ini menggambarkan bagaimana peningkatan penguasaan siswa terhadap materi pelajaran.

Hasil belajar siswa juga ditentukan oleh peran seorang guru dalam proses pembelajaran. Abidin menyatakan peran guru sebagai motivator dan fasilisator dalam proses pembelajaran sangat membantu siswa dalam belajar. Hal ini sejalan dengan teori belajar kognitif yang menyatakan bahwa pembelajarn dapat dikatakan sebagai upaya guru untuk memberikan stimulus, bimbingan, pengarahan, dan dorongan kepada siswa agar terjadi proses belajar[1]. Hal ini sesuai juga dengan pernyataan Discroll yang menyatakan bahwa hasil belajar muncul dari dalam diri siswa merupakan akibat interaksi siswa dengan lingkungannya[8]. Dari penjelasan diatas dapat disimpulkan bahwa penerapan model inkuiri terbimbing dapat meningkatkan hasil belajar aspek pengetahuan siswa kelas XI IPA 4 SMA Negeri 1 Mukomuko.

\section{Hasil Belajar Aspek Keterampilan}

Berdasarkan penelitian dapat dilihat bahwa hasil belajar aspek keterampilan tiap siklusnya mengalami peningkatan di setiap siklusnya. siklus I dengan skor 72.3 dikatagorikan 
cukup terampil. Pada siklus I masih terdapat 26 siswa yang cukup terampil. Pada siklus II terjadi peningkatan, hal ini terlihat dari skor rata-rata siklus II sebesar 77,8 dan masih masuk pada predikat terampil (B). Pada siklus III hasil belajar aspek keterampilan siswa meningkat lagi dari siklus I dan II dengan nilai keterampilan siklus III yaitu 84 dengan predikat terampil (B). Data ini menunjukan kemampuan siswa pada aspek keterampilan sudah terampil. Siswa sudah dikategorikan terampil dalam melakukan percobaan maupun membuat laporan. Siswa sudah dikategorikan terampil dalam melakukan percobaan dan membuat laporan. Secara keseluruhan sudah mengalami peningkatan, siswa sudah sangat terampil dalam melakukan percobaan, menggunakan alat, melakukan pengamatan percobaan, dan berdiskusi dalam menjawab pertanyaan percobaan. Selain itu setiap kelompok juga sudah sanggat terampil dalam merumuskan masalah, menyusun data percobaan, mengumpulkan dan analisis data percobaan , menjawab pertanyaan percobaan dan menyimpulkan hasil percobaan. Data ini menunjukkan bahwa kemampuan keterampilan siswa secara individu siswa mengalami peningkatan dengan mengikuti proses pembelajaran yang menerapkan model pembelajaran inkuiri terbimbing.

Berdasarkan uraian diatas, peningkatan hasil belajar siswa aspek keterampilan dalam proses pembelajaran juga dipengaruhi oleh peningkatan aktivitas belajar siswa, sehingga dapat disimpulkan bahwa peningkatan hasil belajar juga aspek keterampilan merupakan dampak yang ditimbulkan dari meningkatnya aktivitas belajar siswa. Sesuai dengan Permendikbud No. 54 Tahun 2013 yang menyatakan keterampilan diperoleh melalui aktivitas (mengamati, menanya, mencoba, menalar, menyaji,dan mencipta)[1].

Hal ini sejalan pula dengan penelitian yang dilakukan oleh Hasanudin yang menyatakan bahwa "meningkatnya hasil belajar siswa juga dipengaruhi oleh peningkatan aktivitas belajar siswa"[2].

\section{Deskripsi Aktivitas Belajar Siswa}

Berdasarkan hasil penelitian pada proses pembelajaran menerapkan model pembelajaran inkuiri terbimbing dengan pendekatan saintifik, dari tiga siklus yang telah dilaksanakan terdapat peningkatan aktivitas belajar siswa. Peningkatan aktivitas siswa terjadi di setiap siklusnya, pada siklus I memperoleh skor rata-rata yaitu 38, aktivitas siswa kemudian meningkat pada siklus II menjadi 42, kemudian meningkatan lagi pada siklus III menjadi 46.5. Pada pemberian skor oleh pengamat untuk beberapa aspek pengamatan terdapat perbedaan. Perbedaan penilaian ini disebabkan karena beberapa hal diantaranya yaitu perbedaan pandangan dari masing-masing pengamat terhadap aspek yang dinilai dan fokus masing-masing penngamat dalam mengamati, namun secara keseluruhan skor aktivitas siswa berdasarkan penilaian pengamat tetap mengalami peningkatan tiap siklusnya. Aktivitas belajar siswa mengalami peningkatan juga tidak lepas dari adanya interaksi yang lebih baik antara sesama siswa setiap kelompok dan juga interaksi antara guru dan siswa.

Aktivitas guru juga sangatlah penting dalam proses pembelajaran, dimana guru harus berupaya menciptakan kondisi belajar siswa, mendorong siswa untuk belajar bahkan memberikan kesempatan kepada siswa untuk berperan aktif dalam proses pembelajaran, hal ini sesuai dengan Sardiman bahwa mengajar diartikan sebagai suatu aktivitas mengorganisasikan atau mengatur lingkungan sebaik-baiknya dan menghubungkan anak, untuk menciptakan kondisi yang kondusif untuk berlangsungnya kegiatan pembelajaran[7]. Hal ini sejalan juga dengan pendapat Abidin yang menyatakan pembelajaran adalah serangkaian aktivitas yang dilakukan siswa guna mencapai hasil belajar tertentu di bawah bimbingan, arahan, dan motivasi guru[1].

Berdasarkan uraian di atas, aktivitas belajar siswa dalam mengikuti pembelajaran dangan penerapan model inkuiri terbimbing telah mengalami peningkatan dan perbaikan.

\section{SIMPULAN DAN SARAN \\ 4.1 Simpulan}

Penerapan model pembelajaran inkuiri terbimbing pada konsep Alat-Alat Optik dapat 
meningkatkan sikap ilmiah siswa kelas XI IPA 4 SMAN 1 Mukomuko, yaitu jumlah siswa pada kategori baik meningkat pada siklus I sampai siklus III. Selain itu juga dapat meningkatkan hasil belajar siswa pada aspek pengetahuan dan aspek keterampilan siswa, dimana ketuntasan belajar klasikal siklus I pada kategori belum tuntas, ketuntasan belajar klasikal meningkat pada siklus II namun masih pada kategori belum tuntas dan ketuntasan belajar klasikal siklus III meningkat lagi dan sudah masuk kategori tuntas. Sedangkan hasil belajar aspek keterampilan siklus I dengan kategori cukup terampil, meningkat pada siklus II dengan kategori terampil dan pada siklus III meningkat lagi namun masih pada kategori terampil. Serta dapat meningkatkan aktivitas belajar siswa dimana nilai rata-rata aktivitas belajar siswa sudah kategori baik, dan meningkat dari siklus I sampai siklus III.

\subsection{Saran}

Untuk dapat meningkatkan aktivitas belajar siswa, sikap ilmiah dan hasil belajar, disarankan kepada guru untuk memahami betul langkah-langkah model pembelajaran inkuiri terbimbing serta dapat mengatur waktu dalam proses pembelajaran. Kemudian pada saat melakukan percobaan guru harus lebih optimal dalam membimbing siswa sesuai dengan prosedur percobaan agar hasil belajar (aspek keterampilan) yang didapatkan lebih maksimal. Dan untuk penelitian selanjutnya sebaiknya indikator sikap ilmiah diteliti secara keseluruhan namun harus tetap disesuaikan dengan materi pelajaran, percobaannya, dan model pembelajaran yang digunakan.

\section{DAFTAR PUSTAKA}

[1] Abidin, Y. (2014). Desain Pembelajaran Dalam Konteks Kurikulum 2013. Bandung: Refika Aditama.

[2] Hasanudin, M. (2016). "Penerapan Model Berbasis Masalah (Problem Based Learning Model) dengan Pendekatan Saintifik untuk Meningkatkan Hasil Belajar pada Konsep Fluida Statis di Kelas X MIA 1 SMAN 3 Kota Bengkulu”. Skripsi FKIP UNIB: tidak di terbitkan

[3] Jihad, A., \& Haris, A. (2013). Evaluasi Pembelajaran. Yogyakata: Multi Pressindo.

[4] Kemendikbud. (2013). Pendekatan Scientific (Ilmiah). Jakarta: Kementerian Kebudayaan Dan Pendidikan.

[5] Maizora, Faiza. (2015). "Penerapan Model Inkuiri Terbimbing Untuk meningkatkan Sikap Ilmiah dan hasil Belajar Fisika Siswa pada Konsep Kalor di Kelas VII 4 SMPN 03 Kota Bengkulu”. Skripsi FKIP UNIB: tidak di terbitkan

[6] Purwanto, A., \& Lubis, I. S. (2012). Prosiding Seminar Nasional Fisika. Pengaruh Metode Inkuiri Terbimbing Berbasi Laboratorium Ipa Terhadap Peningkatan Hasil Belajar Siswa SMAN 5 Kota Begkulu (p. 171). Palembang: Simetri.

[7] Sardiman, A. (2008). Interaksi \& Motivasi Belajar Mengajar . Jakarta: Raja Grafindo Persada.

[8] Uno, H. B. (2013). Teorimotivasi Dan Pengukurannya. Jakarta: PT. Bumi Aksara. 